\title{
Influence of Independent Variables on Employee Performance in Aceh's Cultural and Tourism Office
}

\author{
Sufitrayati $^{1^{*}}$, Zainuddin $^{2}$, Rita Ningsih $^{3}$, Susanti $^{4}$ \\ ${ }^{1-4}$ Faculty of Economic, Universitas Serambi Mekkah, Aceh, Indonesia \\ *Corresponding Author: sufitrayati@serambimekkah.ac.id
}

\begin{abstract}
This research aims to find out the influence of accounting information systems, internal supervision, and the completeness of tasks on the performance of employees in the Aceh Cultural and Tourism Office. The object of this research is all employees of the office of the Aceh Culture and Tourism Bureau, as many as 186 employees, 36 employees use Sloven technology to draw samples as the result. The sample used in this study is multiple linear regression analysis. As a result of the research, the accounting information system, internal supervision, and completion of tasks simultaneously and partially affect the performance of employees at the Aceh Cultural and Tourism Office.The correlation coefficient $(R)$ value of 0.595 shows that the correlation (relationship) between free variables and bound variables by $59.5 \%$ is that the performance of employees in the work of the Aceh Cultural and Tourism Office has a moderate and positive correlation with the system of accounting issues, internal supervision and task complement age of $87.6 \%$. While the coefficient of determination (R2) of 0.445, is that any changes in employee performance variables can be explained by changes in accounting information system variables, internal supervision, and task completeness of 0.445 or 44.five\% and the remaining 55.five\% explained by other variables beyond the origin of this study can affect employee performance such as leadership style, financial accounting system, internal control system, financial management, and others.
\end{abstract}

Keywords: Employee Performance, Accounting Information Systems, Internal Supervision, and Task Completion.

\section{Introduction}

To realize government governance, financial management is carried out through accounting information systems, the implementation of this system has no guarantee that there are errors or irregularities so that an internal supervision method and the complexity of the task can effectively result in the accounting information system being implemented to run well and improve employee performance. Aceh's Office of Culture and Tourism to fulfill its obligation to provide accountability in providing information about performance to employees. Based on surveys that have been conducted with several employees of the Aceh Office of Culture and Tourism, that employee performance is still low in carrying out the work given such as inappropriate in the making and delivery of reports, rewards, or awards that have not been by employee expectations, inadequate working conditions, less supportive co-worker relationships.

Performance is a result of work achieved by a person in carrying out his duties imposed on him based on skill, experience, and earnestness, and time (Hasibuan, 2013: 94). According to Sedarmayanti (2013: 260) performance is the work of a person, an overall management process, in which the results of one's work must be able to be shown concrete and measurable evidence. 
An accounting information system is a combination of humans and other resources responsible for providing financial information and information obtained through the collection and processing of transaction data in an organization (Jogiyanto, 2013: 49). Burdwan (2013: 4) pointed out that the accounting information system is an organizational component that collects, classifies, processes, analyzes, and communicates financial information related to decision-making. Wahyono (2013: 17) defines an accounting information system as a system created by humans and composed of components in an organization to achieve the goal of information presentation.

According to Mulyadi (2013: 163), internal supervision includes coordination of organizational structure, methods, and measures to maintain organizational wealth, check the accuracy and reliability of accounting data, encourage efficiency and encourage compliance with management policies. According to Terry in Hasibuan (2013: 242), supervision is a process of determination, what must be achieved is standard, what is being done, namely implementation, assessing implementation, and making improvements, so that the implementation by the plan is by the standards. Indonesian Accounting Association (IAI) (2015:319) states that Internal supervision is a process carried out by the board of commissioners, management, and other personnel of the entity designed to provide adequate confidence about the achievement of three objective groups namely (a) reliability of financial reporting, (b) effectiveness and efficient operation, and (c) compliance with applicable laws and regulations.

According to Ruky in Surtikanti and Surya (2015: 3), the complexity of the task depends on the difficulty and degree of change of the work, especially the psychological and psychological pressure on the person engaged in the work. According to Kahneman, et al. (2013:247) defining the complexity of a task is considered identical to a very difficult task (required attention capacity or good mental process) or a complicated task structure (what level of specification to do in the task).

The accounting information system is an arrangement of various recording forms, equipment (including computers and equipment, communication tools, implementation personnel, and closely coordinated reports), which aims to transform financial data into information required for management (Widjajanto, 2013: 4). The accounting information system implemented by the company must be able to help the users of the information system complete their work. Efficient and effective SIA is critical to the long-term success of the organization. Users of accounting information systems influence employee performance.An accounting information system is an arrangement of various recording forms and equipment (including computers and equipment, communication tools, executives, and closely coordinated reports), which aims to transform financial data into information required for management (Widjajanto, 2013: 4). The accounting information system implemented by the company must be able to help the users of the information system complete their work. Efficient and effective, SIA is critical to the long-term success of the organization. Users of accounting information systems have an impact on employee performance.

\section{Hypothesis Development}

Internal supervision includes coordination of organizational structure, methods, and measures to maintain organizational wealth, check the accuracy and reliability of accounting data, encourage efficiency and encourage compliance with management policies (Mulyadi 2013: 163). Likewise, information in internal supervision will have a good impact on improving employee performance. This event is in line with research conducted by Yusmalizar (2014) and Dewi and Fadjar Harimurti (2017) stating that internal supervision affects employee performance. Here, decision-makers are required to develop their mindset, 
creativity, and innovation so that complex tasks can be completed smoothly (Mahdy, 2012: 8). So that the complexity of the task will improve employee performance as done by Parjanti, Hendra, and Nurlela (2014) that the complexity of the task affects employee performance. According to Sugiyono (2014: 60), the mental framework is a conceptual model that shows how the theory relates to various factors that have been identified as important. The schematic diagram of the research framework of this study is shown in Figure 1.

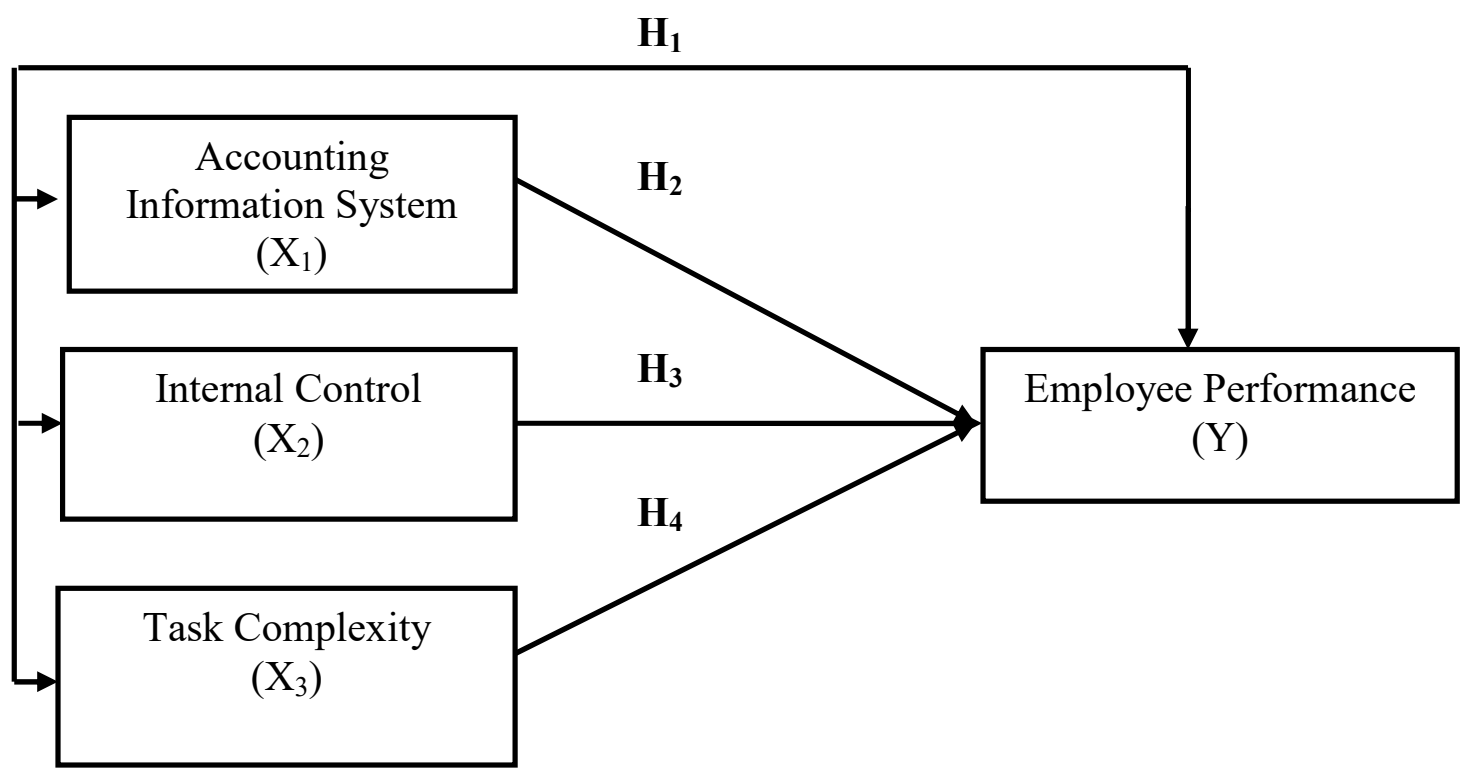

Figure 1. Thinking Framework

Research Hypothesis

According to Sugiyono (2014: 64), the research hypothesis is a temporary answer to the formulation of research problems, where the formulation of research has been expressed in the form of statement sentences. The hypotheses in this study are as follows:

H1: The accounting information system, internal supervision, and task complexity also affect the performance of the employees of the Aceh Culture and Tourism Office.

$\mathrm{H} 2$ : The accounting information system affects the performance of employees at the Aceh Office of Culture and Tourism.

H3: Internal supervision affects the performance of employees at the Aceh Office of Culture and Tourism.

H4: The complexity of the task affects the performance of employees at the Aceh Office of Culture and Tourism.

\section{Method}

In this study, the authors used a quantitative approach. Creswell (2010, p. 24) states that Quantitative approaches are measurements of quantitative data and objective statistics through scientific calculations derived from a sample of people or populations who are asked to answer several questions about surveys to determine the frequency and percentage of their responses." Pop The population is a generalization area consisting of objects or subjects that have certain qualities and characteristics set by researchers to be concluded. Although the sample is the number owned by the population and part of the village (Sugiyono, 2014: 91). The population of this study is all employees in the Aceh Office of Culture and Tourism as 
many as 186 employees. In this study, the number of samples using the in formula is as follows:

$n=\frac{N}{1+N e^{2}}$

Where:

n: Sample size

N: Population Size

e: Percentage of thoroughness due to sampling errors.

In the population using the $15 \%$ Slovenian formula, the minimum number taken is:

$$
\begin{aligned}
\mathrm{n} & =\frac{186}{1+186(0,15)^{2}} \\
\mathrm{n} & =\frac{186}{1+186(0,0225)} \\
\mathrm{n} & =\frac{186}{5,185} \\
\mathrm{n} & =35,87 \text { rounded up to } 36 \text { people. }
\end{aligned}
$$

So, the sample taken was as many as 36 employees at the Aceh Office of Culture and Tourism. The sample extraction is done by the slovin method. The results of the sample division can be seen in Table 1 .

Table 1. Results of the distribution of samples based on the population

\begin{tabular}{|l|l|c|c|}
\hline No & \multicolumn{1}{|c|}{ Part Name } & $\begin{array}{l}\text { Number of } \\
\text { Employees }\end{array}$ & Sample \\
\hline 1 & Head of departmental & 1 & 1 \\
\hline 2 & Secretariat & 33 & 6 \\
\hline 3 & Planning and reporting & 14 & 3 \\
\hline 4 & Customs and cultural values & 13 & 2 \\
\hline 5 & Language and Art Center for & 15 & 3 \\
\hline 6 & Strategic and Policy Studies (PPSK) & 10 & 2 \\
\hline 7 & Destination Development & 15 & 3 \\
\hline 8 & Marketing & 11 & 2 \\
\hline 9 & Tourism Business Development & 10 & 2 \\
\hline 10 & The security guard (PNS) & 6 & 1 \\
\hline 11 & UPTD Museum Aceh & 33 & 6 \\
\hline 12 & UPTD Taman Budaya & 25 & 5 \\
\hline Total & & $\mathbf{1 8 6}$ & $\mathbf{3 6}$ \\
\hline
\end{tabular}

Source: Aceh Culture and Tourism Office (2021)

This research is sourced from the collection of primary data and secondary data, primary data that is direct responses in the form of interviews and questionnaires. Secondary data sources are records or documentation. According to Sugiyono (2014:224). Data analysis 
tools using multiple regression analysis are used to process data. Multiple regression analysis is used in calculating how much influence dependent variables have on independents. According to Sugiyono (2014:277) the formula of multiple regression analysis is as follows:

Where :

$$
\mathbf{Y}=\boldsymbol{\alpha}+\mathbf{b}_{1} \mathbf{X}_{1}+\mathbf{b}_{2} \mathbf{X}_{2}+\mathbf{b}_{3} \mathbf{X}_{3}+\mathrm{e}
$$

$\mathrm{Y} \quad=$ Employee Performance

$\alpha \quad=$ Constant

$\mathrm{X}_{1} \quad=$ Accounting Information System

$\mathrm{X}_{2} \quad=$ Internal Control

$\mathrm{X}_{3} \quad=$ Task Complexity

$\mathrm{b}_{1}, \mathrm{~b}_{2}$ dan $\mathrm{b}_{3}=$ Regression coefficient

$e^{\quad}=$ Error term

A validity test is a valid research result when there are similarities between the collected data and the actual data that occurs in the object being studied. Sugiyono (2014:184) states that an indicator is said to be valid, if $\mathrm{n}=36$ and $\alpha=0.05$, then table $=$ 0.320 with the provision of routing $>$ rtable $(0.320)$ valid results and rhitung $<$ rtable $(0.320)$ results are invalid. More details about the results of the validity test can be seen in Table 2 .

Table 2 Validity Test Results

\begin{tabular}{|c|c|c|c|c|c|}
\hline No & Variabel & Item & Score $\mathbf{R}_{\text {hitung }}$ & Score $R_{\text {tabel }}(N=36)$ & Remark \\
\hline \multirow[t]{5}{*}{1} & \multirow{5}{*}{$\begin{array}{l}\text { Employee } \\
\text { Performance } \\
\text { (Y) }\end{array}$} & A1 & 0,961 & \multirow{5}{*}{0,320} & Valid \\
\hline & & A2 & 0,803 & & Valid \\
\hline & & $\mathrm{A} 3$ & 0,933 & & Valid \\
\hline & & A4 & 0,911 & & Valid \\
\hline & & $\mathrm{A} 5$ & 0,961 & & Valid \\
\hline \multirow[t]{5}{*}{2} & \multirow{5}{*}{$\begin{array}{l}\text { Accounting } \\
\text { Information } \\
\text { System }\left(X_{1}\right)\end{array}$} & B1 & 0,393 & \multirow{5}{*}{0,320} & Valid \\
\hline & & $\mathrm{B} 2$ & 0,474 & & Valid \\
\hline & & B3 & 0,557 & & Valid \\
\hline & & B4 & 0,399 & & Valid \\
\hline & & B5 & 0,408 & & Valid \\
\hline \multirow[t]{5}{*}{3} & \multirow{5}{*}{$\begin{array}{l}\text { Internal } \\
\text { Control }\left(\mathrm{X}_{2}\right)\end{array}$} & $\mathrm{C} 1$ & 0,684 & \multirow{5}{*}{0,320} & Valid \\
\hline & & $\mathrm{C} 2$ & 0,366 & & Valid \\
\hline & & $\mathrm{C} 3$ & 0,852 & & Valid \\
\hline & & $\mathrm{C} 4$ & 0,875 & & Valid \\
\hline & & $\mathrm{C} 5$ & 0,458 & & Valid \\
\hline \multirow[t]{5}{*}{4} & \multirow{5}{*}{$\begin{array}{l}\text { Task } \\
\text { Complexity } \\
\left(\mathrm{X}_{3}\right)\end{array}$} & D1 & 0,473 & \multirow{5}{*}{0,320} & Valid \\
\hline & & D2 & 0,478 & & Valid \\
\hline & & D3 & 0,468 & & Valid \\
\hline & & $\mathrm{D} 4$ & 0,525 & & Valid \\
\hline & & D5 & 0,699 & & Valid \\
\hline
\end{tabular}

Source: Primary Data, 2021 (processed)

In Table 2, the results of the validity test on each variable have the lowest values, namely: (1) the employee performance variable which consists of 5 (five) statement items denoted by item codes A1 to A5 shows the lowest count of 0.803 which is greater than the value table $(\mathrm{n}=36)$ is 0.320 , then all employee performance statement items are declared valid. (2) the accounting information system variable which consists of 5 (five) statement items with item codes B1 to B5, shows the lowest count value of 0.393 which is greater than the table value $(n=36)$ of 0.320 , then all items of the accounting information system statement 
are stated valid. (3) the internal control variable consisting of 5 (five) statement items is symbolized by item codes $\mathrm{C} 1$ to $\mathrm{C} 5$, that the lowest count value of 0.366 is greater than the table value $(n=36)$ of 0.320 , then all items of internal control statements are declared valid (4) the task complexity variable consisting of 5 (five) statement items is symbolized by item code D1 to D5, that the lowest rcountvalucouvalue is greater than the rtablevalutable value 0.320 , then all task complexity statement items are declared valid

\section{Reliability Test}

A reliability test is an instrument that, when used multiple times to measure the same object, generates the same data. The tool for measuring reliability is Cronbach alpha. According to Sugiyono (2014: 196,) a variable is said to be reliable, if the result $\alpha \geq 0.60=$ reliable and the result $\alpha \leq 0.60=$ not reliable. For more details, you can see Table 3 .

Tabel 3. Reliability Test Results

\begin{tabular}{|l|l|l|l|l|}
\hline No & Variables & $\begin{array}{l}\text { Number } \\
\text { of Value } \\
\text { Items }\end{array}$ & $\begin{array}{l}\text { Number of } \\
\text { Value } \\
\text { Items }\end{array}$ & $\begin{array}{l}\text { Number of } \\
\text { Value Items }\end{array}$ \\
\hline 1 & Employee Performance(Y) $(\mathrm{Y})$ & 5 & 0,828 & Reliable \\
\hline 2 & Accounting Information System $\left(\mathrm{X}_{1}\right)$ & 5 & 0,697 & Reliable \\
\hline 3 & Internal Control $\left(\mathrm{X}_{2}\right)$ & 5 & 0,761 & Reliable \\
\hline 4 & Task Complexity $\left(\mathrm{X}_{3}\right)$ & 5 & 0,686 & Reliable \\
\hline
\end{tabular}

Source: Primary Data, 2021 (processed)

According to Table 3, we can know that each variable of Cronbach alpha, that is, the employee performance variable (Y) obtained a value of 0.828 , accounting information system variable (X1) obtained a value of 0.697 , internal supervision variable $(\mathrm{X} 2)$ obtained a value of 0.761 and variable task complexity (X3) obtained a value of 0.686 , then reliability measurements of each research variable meet the credibility of Cronbach alpha $\geq 0,60$.

\section{Results and Discussions}

The normality test is a necessary condition for determining the type of statistics used in subsequent analyses (Sugiyono, 2014: 75). SPSS's normality test can use a variety of tests, such as the Kolmogorov Smirnov test, Shapiro Wilk, and normal probability plot. The result of datum processing resulting in a normal probability plot can be seen in Figure 2.

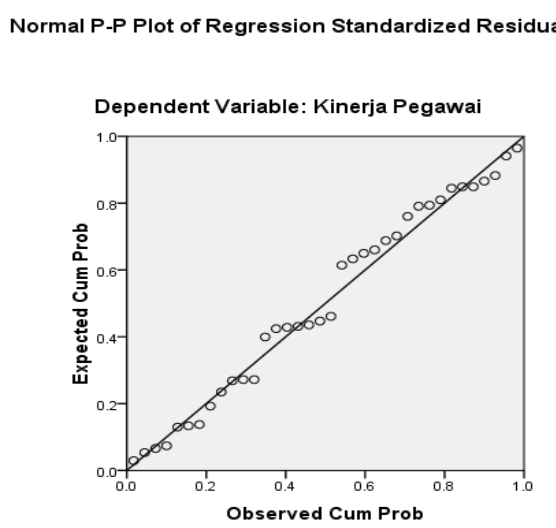

Figure 2. Normal Probability Plot Data Normality Test Results 
In Figure 2, it can be seen that the line describing the data follows its diagonal line so that it can be interpreted that the data used in this study is normally distrib. Ed.

Multicollinearity Test

The purpose the of multiplicity test is to test whether the regression model finds the correlation between free variables or independent variables. Multicollinearity test is seen from toleration and Variance Inflation Factor (VIF) (Ghozali, 2013: 95). If the VIF value $\leq$ 10 and the Tolerance $(\mathrm{T})$ value $\geq 0.10$, it means that there is no multicollinearity. Conversely, if the VIF value $\geq 10$ and the Tolerance $(T)$ value $\leq 0.10$, it means that multicollinearity occurs, as seen in Table 4.

Table 4. Multicollinearity Test Results

\begin{tabular}{|l|l|l|l|}
\hline No & Variables & Tolerance & VIF \\
\hline 1 & Accounting Information System $\left(\mathrm{X}_{1}\right)$ & 0,616 & 1,623 \\
\hline 2 & Internal Control $\left(\mathrm{X}_{2}\right)$ & 0,672 & 1,489 \\
\hline 3 & Task Complexity $\left(\mathrm{X}_{3}\right)$ & 0,609 & 1,643 \\
\hline
\end{tabular}

Source: Primary Data, 2021 (processed)

Based on Table 4. It can then be seen that the accounting information system variable (X1) has a tolerance value of $0.616 \geq 10$ and The variance inflation factor (VIF) value is $1,623 \leq 10$, and the tolerance value of the internal monitoring variable (X2) is $0.672 \geq 10$ and The variance inflation factor (VIF) value is $1,489 \leq 10$, the tolerance value of the task complexity variable (X3) is $0.609 \geq 0.10$, and the variance inflation factor (VIF) value is $1,643 \leq 0.10$. So, it can be interpreted that there are no symptoms of multicollinearity.

\section{Heteroscedasticity Test}

The purpose of the heteroscedasticity test is to test whether there is a residual variance inequality from one observation to another in the regression model. If the variance of the residual from one observation to another is different, then heteroscedasticity (Ghozali, 2013:125). You can use the plot between the predicted values of the bound variable (ZPRED) and the residual (SRESID) to view the heteroscedasticity test, as shown in Figure 3.

Scatterplot

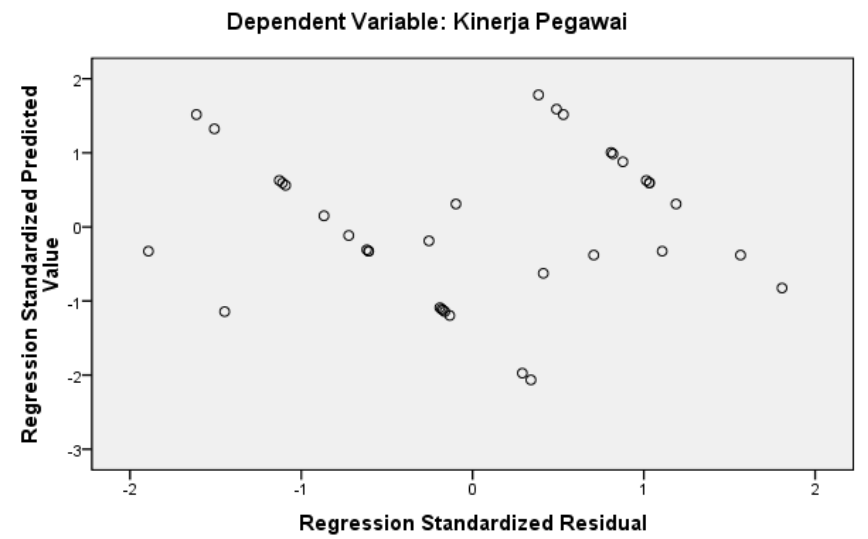

Gambar 3. Grafik Scatterplot 
Based on Figure 3, there is no specific pattern for the scatter plot, and the points are distributed above and below the number 0 on the Y-axis. Thus, it can be interpreted that there are no symptoms of heteroscedasticity.

Based on the results of multiple linear regression tests, it can be seen the results of the hypotheses tested in this study are:

1. Simultaneous Test

Ha1: Prob F value $<$ critical value $(0.003<0.05)$ then, Then He refused to accept it, which means that the accounting information system, internal supervision, and task completion have affected the performance of the employees of the Aceh Culture and Tourism Office.

2. Partial Test

Ha2: Prob value $<$ critical value $(0.002<0.05)$ then Ho rejected Ha accepted, meaning that the accounting information system partially affects employee performance at the Aceh Office of Culture and Tourism.

Ha3: Prob value $<$ critical value $(0.001<0.05)$ then Ho rejected Ha accepted, meaning that internal supervision partially affects employee performance at the Aceh Office of Culture and Tourism.

Ha4: Prob value $\mathrm{t}<$ critical value $(0.000<0.05)$ then Ho rejected Ha accepted, meaning that the completeness of the task partially affects employee performance at the Aceh Office of Culture and Tourism.

Discussions

By the data analysis tools used to determine the functional relationships among the variables studied in the study using multiple linear regression analysis. To see the magnitude of the influence of accounting information systems, internal supervision, and the completeness of tasks on employee performance at the Aceh Office of Culture and Tourism, it can be shown by the regression coefficient value of each variable as seen in Table 5.

Table 5. Independent Variable Regression Coefficient Value

Coefficient

\begin{tabular}{|c|c|c|c|c|c|c|c|}
\hline \multirow[b]{2}{*}{ Model } & \multicolumn{2}{|c|}{$\begin{array}{l}\text { Unstandardized } \\
\text { Coefficients }\end{array}$} & $\begin{array}{l}\text { Standardiz } \\
\text { ed } \\
\text { Coefficient } \\
\mathrm{s}\end{array}$ & \multirow[b]{2}{*}{$\mathrm{t}$} & \multirow[b]{2}{*}{ Sig. } & \multicolumn{2}{|c|}{$\begin{array}{l}\text { Collinearity } \\
\text { Statistics }\end{array}$} \\
\hline & $\mathrm{B}$ & $\begin{array}{l}\text { Std. } \\
\text { Error }\end{array}$ & Beta & & & VIEW & VIF \\
\hline 1ts (Constant) & 22.767 & 6.641 & & 3.428 & .002 & & \\
\hline $\begin{array}{l}\text { Accounting } \\
\text { Information System }\end{array}$ & .238 & .266 & .154 & 3.834 & .002 & .616 & 1.623 \\
\hline Internal Control & .405 & .229 & .331 & 4.768 & .001 & .672 & 1.489 \\
\hline Task Complexity & .565 & .337 & .331 & 5.680 & .000 & 609 & 1.643 \\
\hline
\end{tabular}

a. Dependent Variable: Employee

Performance

Source: Primary Data, 2021 (processed) 
Based on Table 5, the multiple linear regression equation can be formulated as follows:

$$
Y=22,767+0,238 X_{1}+0,405 X_{2}+0,565 X_{3}+e
$$

Based on the results of the double linear regression analysis that the constant value of 22,767 means that if the accounting information system, internal supervision, and complexity of tasks together or together do not change or equal to zero (0), then the amount of employee performance at the Aceh Office of Culture and Tourism is 22,767 units. While those that have a dominant influence on employee performance at the Aceh Office of Culture and Tourism are task complexity variables (X3) of 0.565 or $56.5 \%$, then internal supervision variables (X2) of 0.405 or $40.5 \%$ and followed by accounting information system variables (X1) of 0.238 or $23.8 \%$.

Correlation Coefficient and Determination

The relationship and impact of variables in the accounting information system of the Aceh Culture and Tourism Bureau, internal supervision, and completeness of responsibilities on employee performance are shown in Table 6.

Table 6. Value of Correlation Coefficient (R) and Determination (R2)

Summary

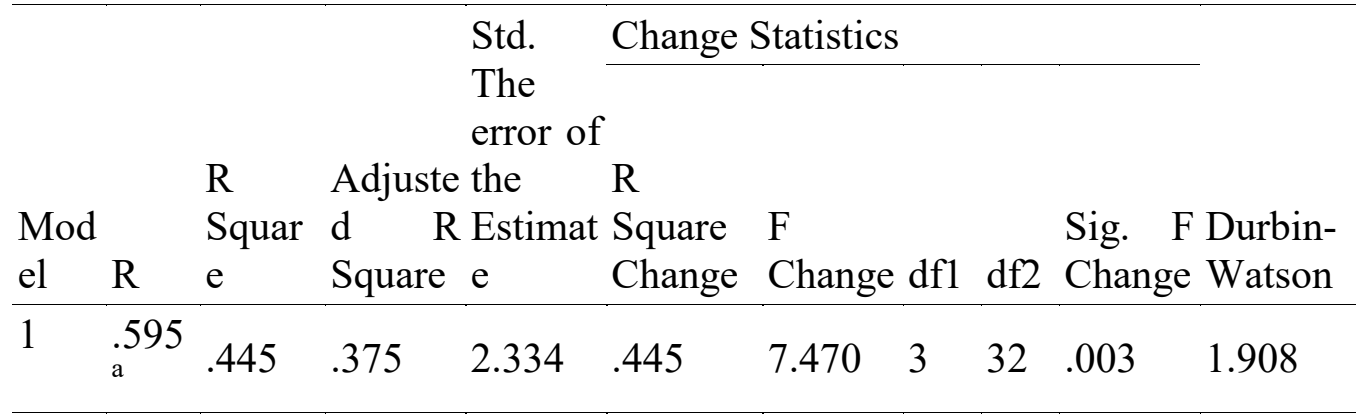

a. Predictors: (Constant), Task Complexity, Internal

Control, Accounting Information System

b. Dependent Variable:

Employee Performance

Source: Primary Data, 2021 (processed)

Based on Table 6. The correlation coefficient (R) of 0.595 shows that the relationship (correlation) between independent variables and dependent variables is $59.5 \%$, meaning that the performance of employees at the Aceh Office of Culture and Tourism has a moderate and positive relationship with the accounting information system, internal supervision and task completeness of $59.5 \%$. While the coefficient of determination (R2) of 0.445 , meaning that any changes in employee performance variables can be explained by changes in accounting information system variables, internal supervision and task completeness of 0.445 or $44.5 \%$ and the remaining $55.5 \%$ described by other variables outside of this study can affect employee performance such as leadership style, financial accounting system, internal control system, financial management, and others.

Based on the results of research and proof of the hypothesis that the accounting information system, internal supervision, and task completeness simultaneously affect employee performance in the Aceh Office of Culture and Tourism, with the value of prob $\mathrm{F}$ and crisis value is $0.003<\alpha=0.05$, this shows that the accounting information system, 
internal supervision, and task completeness simultaneously have a significant effect on employee performance at the Aceh Office of Culture and Tourism, Thus the first hypothesis (Ha1) is accepted. This is by the results of research conducted by Parjanti Hendra and Nurlela (2014), Yusmalizar (2014), and Dewi and Fadjar Harimurti (2017), and Pradhika and Pratiwi (2017) stated that accounting information systems, internal supervision, and task complexity affect employee performance. As a result, the higher the complexity of the accounting information system, internal supervision, and tasks, the higher the performance of employees.

The accounting information system partially affects the performance of employees in the Aceh Office of Culture and Tourism, with the value of prob $\mathrm{T}$ and the crisis value is 0.002 $<\alpha=0.05$, this shows that the accounting information system partially affects the performance of employees at the Aceh Office of Culture and Tourism, thus the second hypothesis (Ha2) is accepted. The regression coefficient of the accounting information system variables is 0.238 , which means that every unit in the accounting information system will have an impact of 0.238 or $23.8 \%$ on employee performance. This idea is by the results of research conducted by Parjanti Hendra and Nurlela (2014) and Pradhika and Pratiwi (2017) stated that accounting information systems affect employee performance, where the higher the accounting information system, the higher the employee performance will also increase.

Internal supervision partially affects the performance of employees at the Aceh Office of Culture and Tourism, with the value of prob $\mathrm{T}$ and the value of the crisis is $0.001<\alpha=$ 0.05 , this shows that internal supervision partially affects the performance of employees in the Aceh Office of Culture and Tourism, thus the third hypothesis (Ha3) is accepted. The result is that the regression coefficient of the internal supervision variable is 0.405 , that is, every unit of internal supervision that occurs will have an impact of 0.405 or $40.5 \%$ on employee performance. This idea is by the results of research conducted by Yusmalizar (2014) and Dewi and Fadjar Harimurti (2017) stated that internal supervision affects employee performance, where the more internal supervision than employee performance will also increase.

The distribution of duties partially affects the performance of employees in the Aceh Office of Culture and Tourism, with the value of prob $\mathrm{T}$ and the value of the crisis is $0.000<$ $\alpha=0.05$, this shows that the completeness of the task partially affects the performance of employees in the Aceh Office of Culture and Tourism, thus the fourth hypothesis (Ha4) is accepted. Due to the regression coefficient value of the task completeness variable by 0.565 , meaning that if the task completeness occurs by 1 unit, it will affect employee performance by 0.565 or $56.5 \%$. This is consistent with the findings of Parjanti, Hendra, and Nurlela (2014) that the complexity of tasks affects employees' performance, and the higher the complexity of the task, the greater the employee's performance.

\section{Conclusions}

Based on the results of the previously outlined research and discussion, the following conclusions can be drawn:

1.Accounting information systems, internal supervision, and task completeness simultaneously affect employee performance at the Aceh Office of Culture and Tourism.

2. The accounting information system partially affects employee performance at the Aceh Office of Culture and Tourism. 
3. Internal supervision partially affects employee performance at the Aceh Office of Culture and Tourism.

4. The completeness of duties partially affects the performance of employees at the Aceh Office of Culture and Tourism.

\section{References}

Bada, N. S., and Erna, H. (2014). Pengaruh Insentif, Pengalaman Dan Kompleksitas Tugas Terhadap Audit Judgment. Jurnal. Simposium Nasional Akuntansi VIII Solo.

Dewi., Harimurti, F. (2017). Pengaruh Pengawasan Internal, Sistem Akuntansi Keuangan Daerah Dan Pengelolaan Keuangan Daerah Terhadap Kinerja Keuangan pada DPPKAD Kabupaten Karanganyar. Jurnal. Universitas Slamet Riyadi: Surakarta.

Ghozali, I. (2013). Aplikasi Analisis Multivariate Dengan Program SPSS. Jakarta: Badan Penerbit Universitas Diponegoro.

Hanum, Z., and Agustina. (2017). Pengaruh Sistem Pengendalian Internal Pemerintah Dan Pemahaman Sistem Informasi Akuntansi Terhadap Kinerja Keuangan (Studi pada Dinas dan Badan Pemerintah Kabupaten Aceh Utara). Jurnal Akuntansi dan Pembangunan. Politeknik Negeri Lhokseumawe.

Ikatan Akuntan Indonesia. (2015). Standar Akuntansi Keuangan. Salemba Empat: Jakarta.

Iskandar, Z. M.H. (2011). Effects Of Goal Orientation and Task Complexity On Audit Judgement Performance. Malaysian Accounting Review. Universiti Kebangsaan Malaysia: Selangor, Malaysia.

Jogiyanto. (2013). Analisis \& Desain Sistem Informasi: Pendekatan Terstruktur: Teori dan Praktek Aplikasi Bisnis. Yogyakarta: Penerbit Andi Offset.

Kahneman. (2013). On The Psychology of Prediction. United States: Penguin Books Ltd.

Mahdy, E. (2012). Analisis Pengaruh Locus Of Control Dan Kompleksitas Tugas Terhadap Kinerja Audit Internal (Studi Pada Auditor Internal Pemerintah Yang Bekerja Pada Inspektorat Provinsi Jawa Tengah. Skripsi. Universitas Diponegoro. Semarang.

Mathis, R. R., and Jackson, J. H. (2013). Human Resource Management. Jakarta: Penerbit Salemba Empat.

Nawawi, H. (2012). Evaluasi dan Manajemen Kinerja di Lingkungan Perusahaan dan Industri. Yogyakarta: Gadjah Mada University Press.

Nugroho, F. A. (2013). Pengaruh Pengawasan, Pemahaman Sistem Akuntansi Keuangan Dan Pengelolaan Keuangan Terhadap Kinerja Unit Satuan Kerja Pemerintah Daerah (Studi Kasus Dinas pendapatan Pengelolaan Keuangan Dan Aset Daerah (DPPKAD) SeEkskarisidenan Surakarta). Jurnal Akuntansi. Universitas Muhammadiyah Surakarta.

Parjanti H., and Nurlela. (2014). Pengaruh Sistem Informasi Akuntansi, Gaya Kepemimpinan Dan Kompleksitas Tugas Terhadap Kinerja Pegawai. Jurnal Paradigma Vol. 12, No. 01. Fakultas Ekonomi Jurusan Akuntansi Universitas Islam Batik Surakarta

Pradhika., and Pratiwi. (2017). Pengaruh Sistem Informasi Akuntansi, Gaya Kepemimpinan Dan Motivasi Kerja Terhadap Kinerja Pegawai Bagian Akuntansi Pada PT. Indoagung Surya Motor Semarang. Jurnal Akuntansi. Universitas Dian Nuswantoro Semarang

Puspitasari, N. (2011). Penilaian Hubungan Insentif Kinerja, Usaha, dan Kompleksitas Tugas Terhadap Kinerja Audit Judgment. Skripsi tidak dipublikasikan, Fakultas Ekonomi Universitas Diponegoro: Semarang.

Surtikanti, and Sunarya (2015). Pengaruh Kompleksitas Tugas Dan Skeptisme Profesional Terhadap Audit Judgment (Studi Kasus Pada Kantor Akuntan Publik (KAP) Di Kota Bandung yang terdaftar di BPK RI). Jurnal. Universitas Komputer Indonesia. 
Wahyono, T. (2013). Sistem Informasi Konsep Dasar, Analisis Desain dan Implementasi. ogyakarta: Penerbit Graha Ilmu.

Yusmalizar. (2014). Pengaruh Pengawasan Intern Dan Pengelolaan Keuangan Daerah Terhadap Kinerja Pemerintah Daerah (Studi Empiris Pada SKPD Pemerintah Provinsi Sumatera Barat). Jurnal Akuntansi. Universitas Negeri Padang. 